\begin{tabular}{|c|c|}
\hline \multirow{3}{*}{ 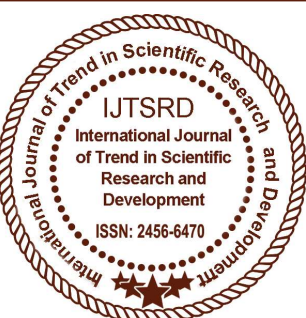 } & $\begin{array}{l}\text { International Journal of Trend in Scientific } \\
\text { Research and Development (IJTSRD) }\end{array}$ \\
\hline & Access Journal \\
\hline & ISSN No: 2456 - 6470 | www.ijtsrd.com | Volume - 2 | Issue -3 \\
\hline
\end{tabular}

\title{
Personal Income Taxes and Growth of Small Firms in Nigeria
}

\author{
John-Akamelu Racheal Chitom \\ Department of Entrepreneur Studies Unit, Faculty of \\ Management Sciences, Nnamdi Azikiwe \\ University, Awka, Nigeria
}

\author{
Iyidiobi Felicia Cheluchi \\ Department of Accountancy, Faculty of Management \\ Sciences, Enugu State University of Science and \\ Technology, Enugu, Nigeria
}

\begin{abstract}
The study determines the effect of tax evasion and avoidance on personal income tax on small firms in Nigeria. The specific objectives are as follows: to determine the effect of personal income tax avoidance affects the growth of small firms in Nigeria and to ascertain the effect of personal income tax rates and tax evasion on the growth of small firms in Nigeria. Survey research design was adopted and one sample ttest was used to test the formulated hypotheses with aid of SPSS Version 20.0. The study found that personal income tax avoidance has no effect the growth of small firms in Nigeria. Another finding is that personal income tax rates and tax evasion affects the growth of small firms in Nigeria. Based on this, the study recommended among others that emphasis should be on enhancing direct assessment through capturing every eligible tax payer and small firms in the state, as it is only when you know the capacity of your people that you could plan successfully.
\end{abstract}

Keywords: personal income, tax avoidance, Tax evasion and the growth of small firms

\section{INTRODUCTION}

Small enterprises always considered an important force for economic development and industrialization in smaller economies (Aryeetey \& Ohene, 2004; Oludele \& Emilie, 2012). (Tee, Boadi and Opoku (2016) were of opinion that these enterprises contributed immensely in jobs creation, poverty eradication as well as economic growth in Africa. According to the 2005 World Development Report, creation of sustainable jobs opportunities for smaller entrepreneurs is the key strategies to take people out of poverty.
Although tax evasion and avoidance are problems that face every tax system, the Nigerian situation seems unique when viewed against the scale of corrupt practices prevalent in Nigeria. Under direct personal taxation as practiced in Nigeria, the major problem lies in the collection of the taxes especially from the self-employed such as the businessmen, contractors, professional practitioners like lawyers, doctors, accountants, architects and traders in shops among others. As observed by many researchers, these persons blatantly refuse to pay tax by reporting losses every year. According to him, many of these professionals live a lifestyle inconsistent with reported income, which is usually unrealistically low for the nature of their businesses. Civil Servants and their salaried workers are the only class of people that actually pay tax in Nigeria. However, even among the salaried workers, he added, many have turned the statutory personal allowances and relief into a fertile ground for tax evasion.

A stated by Alabi, (2001), while it immediately presupposes that there is legal framework put in place to punish tax evaders it perhaps raises a poser on the efficiency and effectiveness of tax laws and tax administration in Nigeria. Some state governments in an effort towards solving this problem had even gone to the extent of engaging the services of tax consultants. This government effort, notwithstanding, the problem of tax evasion and avoidance still persists The previous studies have done well in this particular are but fail to cover how personal income taxes administration affect the growth of small firms in the country. This forms the significant of this study. The study determines the effect of tax evasion and tax 
avoidance on personal income taxes on small firms in Nigeria. The specific objectives are as follows;

1. To determine the effect of personal income tax avoidance on the growth of small firms in Nigeria.

2. To determine the effect of personal income tax rates and tax evasion on the growth of small firms in Nigeria.

\section{REVIEW OF RELATED LITERATURE}

\section{Conceptual Framework}

\section{The Personal Income Tax in Nigeria:}

Adesopo, Agboola \& Akinlo (2004) defined personal income tax as the tax charged on the income of individuals and such an income is divided into two major groups when determining the statutory income of individual or partners in partnership as earned income and unearned income.

In Nigeria, State Governments receive payments in respect of personal income taxes of individuals resident in those states on the first day of the fiscal year, excepting members of the Armed Forces and residents of the capital territory who pay to the Federal Government. Samuel (2010) states that section 1 of the Personal Income Tax Act, 1993 which repealed the Income Tax Management Act 1961 provides that "there is hereby imposed a tax on the income of (a) Individuals, communities and family and (b) Trustee or estate, which shall be determined under and be subject to the provision of this Decree" Thus, the Personal Income Tax Act imposes taxes on individuals who have taxable incomes, partnerships, trustees and executors of settlements, and on family and community incomes (Samuel, 2010).

According to Samuel (2010), the liability to income tax extends in general to: All persons resident in Nigeria, whether Nigerians or not as long as income is derived from Nigeria; All persons not resident, whether Nigerian or not in so far as they derive income from property, trade, profession, vocation or employment in Nigeria.

Personal income tax is often collected on a pay as you earn basis, with small corrections made soon after the end of the tax year. These corrections take one of two forms: payments to the government by tax payers who did not pay enough during the tax year; and tax refunds from the government to those who overpaid. Income tax systems often have deductions available that lessen the total tax liability by reducing total taxable income. They may allow losses from one type of income to be counted against another. For example, a loss on the stock market may be deducted against taxes paid on wages.

\section{Personal Income Tax (Amendment) Act, 2011}

The Personal Income Tax Act Cap P8, LFN 2004, is now amended by the Personal Income Tax (amendment) Act, 2011. This follows many years of agitation for the Personal Income Tax Law in Nigeria to be brought in line with present day economic realities, and also to assist to increase the compliance levels and the amount of tax voluntarily paid and or collected by the Nigerian government.

Ologhodo, (2007) observed that taxpayers in Nigeria heaved/a sigh of relief when the news of the amendment to the Personal Income Tax Act (PITA) spread across the length and breadth of the country. He furthered that the announcement came after a prolonged wait as the Bill was passed by the immediate past sixth Assembly.

The House of Representatives passed the Bill on 25th May, 2011 while the Senate passed it on 1st June, 2011. The news of the President's assent to the Bill to amend the Personal Income Tax Act, Cap P8 LFN 2004 was made public on Tuesday, 13th December, 2011, during the presentation of the 2012 budget proposal by the President to a joint session of the National Assembly.

Expectedly, the Personal Income Tax (Amendment) Act, 2011 has generated series of reactions and flurry of comments, including differing views on some of the controversial aspects. As soon as the Personal Income Tax (Amendment) Act was made public, it was discovered that the date of assent by the President was 14th June, 2011. Till date, it was unclear why taxpayers have to wait for six months before the news of the signed bill became public (Ologhodo, 2007).

Curiously enough, before the President's assent, there were agitations and appeals from taxpayers for its signing. For example, one national newspaper published on 28th October, 2011, reported that Petroleum and Natural Gas Senior Staff Association of Nigeria (PENGASSAN) appealed to the President to sign the Personal Income Tax (Amendment) Bill into law without further delay. 
Some commentators have mentioned that the indicated date of assent helps to avoid a breach of Section 58 of the 1999 constitution which requires the president to signify his assent or the withholding of his assent within thirty (30) days of a Bill being presented to him. Another point is that, it may have been impossible for the president to assent to the bill at any period later than June, 2011 which signified the end of the sixth National Assembly. The legislative rule that was then applicable is to the effect that any Bill that could not be passed at the end of a session of a particular Assembly would go through a fresh legislative process when a new Assembly is inaugurated.

Thankfully, taxpayers do not need to suffer a second round of the waiting game as the President has done justice to the Bill. The new Assembly has also modified its rule which now allows a new Assembly to continue the consideration of Bills that could not be completed during a legislative cycle. A Bill could now survive beyond the lifespan of a particular legislative cycle.

\section{Key Changes:}

i. Introduction of a consolidated tax free allowance of $\mathrm{N} 200,000$ or $1 \%$ of gross income, (whichever is higher), plus $20 \%$ of the gross income. Gross emolument is defined to include benefits in kind, gratuities, superannuation and any other incomes derived solely by reason of employment as against a personal relief of N5,000 plus $20 \%$ of earned income in the old law.

ii. Deleting paragraph $2 \& 3$ under the third schedule that hitherto exempts the official emoluments of the President, Vice President, Governors and Deputy Governors for personal income tax purposes.

i. Personal income exempted from tax include: National Housing Fund (NHF), National Health Insurance Scheme (NHIS), Life Assurance Policies, the National Pensions Scheme and Gratuities.

ii. Principal place of residence is now redefined to include places where branch offices and operational site of companies are situated. Operational sites are defined to include oil terminals, oil platforms, flow stations, construction sites, etc with a minimum of 50 workers.

iii. Increase in minimum tax rate from $0.5 \%$ to $1 \%$ of gross income

iv. Benefit in kind now specifically included in gross emolument and by implication, taxable income.

v. Temporary staff now specifically liable to tax. This will include casual workers, interns and other contract staff.

vi. Reimbursement and expense claims still applicable as the relevant provision of the law was not deleted by the amendments. Also it cannot be argued that reimbursements (by their nature) are included in consolidated allowance.

viii. Appeal against unresolved assessment to be handled by the Tax Appeal Tribunal

ix. $\quad 1 \%$ bonus for early filing of assessment by individuals has been removed.

x. Provision for the refund of excess withholding tax (WHT) and interest on withholding tax (WHT) default to be at the Central Bank of Nigeria Monetary Policy Rate (MPR).

xi. Cle Interest on default in payment of tax due to be at bank base lending rate to be imposed on an annual basis from the date when the tax becomes due until it is paid. This means simple interest will now be charged against the current practice of a flat rate (one off) interest.

xii. New tax table rate is as below:

\section{NEW BANDS (N) NEW RATES (\%)}

First 300,000

Next 300,000

Next 500,000

Next 500,000

Next $1,600,000$

Above 3,200,000

The Personal Income Tax (Amendment) Act 2011: Implementation and Matters Arising:

The Personal Income Tax (Amendment) Act 2011 was officially gazetted on Tuesday 31 January 2012 with an effective date of 14 June 2011. 
Regardless of where an employer is on the implementation phase, there are a number of issues arising from implementation that are likely to affect the employer.

Employee benefits are generally taken to be all forms of consideration given by an establishment in exchange for service rendered by employees "including short-term benefits such as wages, salaries, holiday pay, sick leave and bonuses; long-term benefits such as long-term incentive plans and longservice awards; termination benefits such as redundancy payment; and post-employment benefits such as pensions and post-retirement medical insurance (Oyedele, 2012).

\section{Taxation System in Nigeria}

The Nigeria tax system is basically structured as a tool for revenue generation. This is a legacy from the pre-independence government based on 1948 British tax laws and have been mainly static since enhancement. The need to tax personal incomes throughout the country prompted the income tax management act (ITMA) of 1961.

In Nigeria, personal income tax (PIT) for salaried employment is based on a pay as you earn (PAYE) system, several amendments have been to the 1961 ITIMA Act. For instance, in 1985 PIT was increased from N600 or 10 percent of earned income to N2000 plus 12.5 percent of income exceeding N6000. In 1989, a 15 percent withholding tax was applied to savings deposits valued at N50000 or more while tax on rental income was extended to cover charted vessels, ships or air craft. In additions, tax on the fees of directors was fixed at 15 percent, these policies were geared to achieving effective protection for local industrial, greater use of raw materials, generating increased government revenue among other (Mamud, 2008) consequently, and attention has been focused on promoting exports for manufactures and reducing the tax burned of individual and companies. In line with this change in policy focus, many measures were undertaken. These involved, among others, reviewing custom exemption and rebats introduction capital allowanced, expending the duty drawback scheme and manufacturing-in-blood scheme, abolisng excise duty. Implementation VAT, monetizing firings benefits and increased tax relief to low income earners.

Nigeria operates what is generally known as a federal tax system. In this respect, the present structure of taxation as stipulated by the Constitution of the
Federal Republic of Nigeria reflects the three-tier system of Government at the Federal, State and Local Government levels. Under the Constitution, each tier of Government has been granted powers and responsibility in respect of the imposition and collection of taxes.

The 1999 Constitution of the Federal Republic of Nigeria places the responsibility for legislating on taxation on Income, Capital Gains and Stamp Duty on the Federal Government as stated in the Exclusive Legislative List. It however places collection of taxes on the concurrent legislative list, enabling the Federal Government to delegate administration or collection of taxes as it pertains to taxation or duty on

(a) Capital gains, incomes or profits of persons other than companies; and

b) Documents or transactions by way of stamp duties, to the State Government.

At the same time, the constitution places the responsibility for legislating on the collection of taxes, fees and charges that can be collected by the Local Government on the State Governments. Other than that specifically stated in the exclusive legislative list, activities that would ordinarily attract taxes, fees and charges (forms of levies) are placed squarely as part of the responsibilities of the Local Government Council - in the 4 th schedule. The above provisions of the Constitution provide a clear indication that taxation is meant to be a collective responsibility of each tier of Government with every tier provided its own powers, areas of jurisdiction and roles

\section{Taxation of SMEs}

Atawodi and Ojeka (2012) explained that, the choice of tax policy to employ depends on the use of one or both two groups of instruments, the first being the use of special tax preferences and the other incentives to support start-up and growth of small companies (Atawodi \& Ojeka, 2012). These incentives comprise of the lowering of corporate income tax rates, special tax exemptions or tax holidays and relieves for small businesses. The underlying reason for all these is to effectively raise revenue through measures that suit a country's circumstances and administrative capacity (Atawodi \& Ojeka, 2012).

Developing countries such as Ghana are usually struggling in terms of raising internal revenues for development. In order to solve this issue, scholars 
have discussed among others that the widening of the tax net is the way to go. This is due to the urgency to provide infrastructure, create jobs and reduce unemployment, expand the productive sectors of the economy and to significantly raise public revenues from the non-oil sectors.

With this process, tax policies are to aim at bringing all taxable adults into the tax bracket with a graduated rate that should ensure that the well-off pay their own share while the low income earners are given savings incentives. An effective and efficient tax administration system should be integral to any country's well-being (Atawodi \& Ojeka, 2012). It is with this notion that Baurer (2005) argues that the tax administration must provide an even playing field for business by ensuring that all taxpayers meet their tax filing and paying requirements.

The authorities and the administrators of taxes should seek to balance their educational and assistance role with the enforcement role. According to Atawodi and Ojeka (2012), the rationale behind the whole system of tax is consistent with two of the three major theories of tax namely; the Ability-to-Pay Principle and the Equal Distribution Principle. The two principles stress equality and fairness. The Ability-toPay theory is of the view that individual should be taxed based on the individuals' ability to pay while on the other breadth, the Equal distribution Principle proposes that the incomes, wealth as well as the monetary transactions of the individuals should be taxed at a fixed percentage. This implies that, the individuals who earn more and buy more should pay more taxes, but will not pay a higher rate of taxes (Atawodi \& Ojeka, 2012).

\section{Tax Compliance and SMEs}

Tax compliance has been seen to be a complex issue to define according to (Marti, 2010). In simple terms, tax compliance can be defined as the fulfillment of all tax obligations as specified by the law freely and completely.

It has been found that regulatory burdens fall excessively on small and medium enterprises (Pope \& Abdul-Jabbar, 2008). The nature and size of small and medium enterprises makes the issue of tax compliance one of particular importance (Atawodi \& Ojeka, 2012). Especially since most SMEs have access to limited resources and inadequate expertise to comply with diverse and complicated regulation. Marti (2010) also believes that high compliance costs can result in tax avoidance, tax fraud, and inhibit investment by way of diminishing competitiveness of the country in terms of taxation attractiveness.

\section{Tax Evasion and Tax Avoidance Practices}

Business owners and Individuals usually have many ways of completing a taxable transaction. Tax planning evaluates different tax options to know how to conduct business and personal transactions in order to reduce or eliminate tax liability.

Though they may sound similar "tax avoidance" and "tax evasion" are radically different. Tax avoidance lowers ones tax bill by structuring ones transactions in order for one to reap the largest tax benefits. Tax avoidance is a complete legal and wise decision (Business Owener, 2016) .

Tax avoidance is the legal use of tax laws to reduce one's tax burden. Turner (1990), described it as using whatever legal means you choose to reduce your current or future tax liabilities. Murray (2010), defined it as the legitimate minimizing of taxes, using methods approved by Inland Revenue Service (IRS). Albinet (1996), opined that it is generally the legal exploitation of the tax regime to one's own advantage, to attempt to reduce the amount of tax that is payable by means that are within the tax law whilst making a full disclosure to the tax authorities.

\section{Empirical Review}

Tee, Boadi and Opoku (2016) in their study survey 102 managers/ Executive officers of the selected SMEs in the Ga West Municipality in the Greater Accra region of Ghana. The survey was administered using questionnaire and interview with the selected respondents. Descriptive analysis was method was used to analyzed data collected; correlation and regression analysis were used to test the hypotheses. Findings shows that majority of the respondents perceive the adverse impact of existing tax policies on the growth of SMEs and suggest for reforming the tax policies in the Country.

Adebisi and Gbegi (2013) examine the effect of tax avoidance and tax evasion on personal income tax administration in Nigeria. The sample size was derived statistically using Yaro Yamane formula. The sample size consists of three hundred and five (305) employees of Federal Inland Revenue Service Abuja. The study utilizes primary and secondary data. The study employed simple percentage tables for the 
analysis. The Analysis of Variance (ANOVA) was used to test the hypotheses. The study found that enlightenment and adequate utilization of tax revenue on public goods will discourage tax avoidance and tax evasion, and high tax rates encourage tax avoidance and tax evasion. The researcher therefore concluded that there is a direct and positive relationship between tax avoidance, tax evasion, tax rates and personal income tax administration in Nigeria.

Nassar and Fasina (2005) examined the income profiles of Oyo state government and assessed the personal income tax impact on the income accruable to the state under the constitution of the Federal Republic of Nigeria. Secondary data were sought from the approved budgets of Oyo state from years 2000-2006 which were used for the study. Stepwise regression technique was used to select the revenue source that has the greatest impact on Internally Generated Revenue (IGR) in the state. Multiple R, R2 and $\mathrm{R} 2 \mathrm{c}$ were determined to analyze the individual cumulative relationship and effect of the revenue sources on IGR respectively. Findings indicate that personal income taxes have the highest contribution of $68.4 \%$ effect on IGR in Oyo state. Both taxes and licences jointly accounted for $68.8 \%$ variation in IGR in the state. Hence, any improved strategy on taxes will boost the state IGR. The study recommends an improved strategy through the use of Electronic Revenue Assessment, Collection and Monitoring technique together with unique taxpayer personal identification number (UTPIN) database to attract both the self-employed and salary earners into the Personal Income Tax net.

In a study carried out by Steenekamp (2012) aimed at examining the impact of personal income tax reforms since 1994 on the tax structure and its scope to meet the challenges of rising needs and equity and to provide a broad outline of personal income tax approaches that are globally considered as alternative reform options, it was found that in South Africa, direct taxes as a percentage of total tax revenue increased in importance between 1993/94 and 2010/11. The personal income tax burden for wage earners in South Africa has remained fairly constant since 1995. The personal income tax structure was progressive, but there was a declining trend in progressivity between 1994 and 2009. Increasing personal income tax rates was constrained by low company tax rates, possible increased efficiency costs and 'herd behaviour'. The income tax system in South Africa conforms to a semi-comprehensive income tax system. He recommended that the tax reform option that holds the most promise for developing countries (and South Africa) is the dual income tax system.

In a study by William \& Andrew (2014), the paper examined how changes to the individual income tax affect long-term economic growth. According to the study, the structure and financing of a tax change are critical to achieving economic growth. Tax rate cuts may encourage individuals to work, save, and invest, but if the tax cuts are not financed by immediate spending cuts they will likely also result in an increased federal budget deficit, which in the longterm will reduce national saving and raise interest rates. The net impact on growth is uncertain, but many estimates suggest it is either small or negative. Base-broadening measures can eliminate the effect of tax rate cuts on budget deficits, but at the same time they also reduce the impact on labour supply, saving, and investment and thus reduce the direct impact on growth. However, they also reallocate resources across sectors toward their highest-value economic use, resulting in increased efficiency and potentially raising the overall size of the economy. The results suggest that not all tax changes will have the same impact on growth. Reforms that improve incentives, reduce existing subsidies, avoid windfall gains, and avoid deficit financing will have more auspicious effects on the long-term size of the economy, but may also create trade-offs between equity and efficiency.

A similar study was carried out by Onyekwelu and Ugwuanyi (2014) examined the effects of Personal Income Tax Amendment Act 2011 on revenue generation in Nigeria, with a view to exposing the possible challenges and prospects it poses to the Nigerian tax payers. Primary data sourced using a structured questionnaire were used. The data collected through the questionnaire were analyzed using chisquare statistical method. The study reveals among other things that the increase in the tax rate affected the tax payers revenue generation, and the retroactive nature of our tax laws constitutes a major problem thus: resulting in double taxation during the assessment and collection of taxes. Following the findings, the researchers recommended that competent laws should be passed by the government on personal Income tax collection and generation, stiff penalties should be imposed on the tax defaulters and evaders, tax laws should be made less complex, recruitment of qualified personnel to enable them cover fully the scope of work and finally the tax payers should be educated sufficiently on the importance of tax. 
Lefebvre et aL (2011) conducted study in Netherlands, France and Belgium (Flanders and Wallonia) while examining the behavior of people. He compared the behavior of people regarding welfare dodging and tax evasion. Results indicated that people adopt less evaded behavior in tax treatment than in welfare treatment; and people evade more tax in Netherlands and France but tax evasion is more in Flemish than Walloons.

Liadiale et al. (2010) conducted study in Nigeria while examining relationship between personal income tax evasion and cultural factors like religiosity, trust in government, and legal enforcement. Study found positive impact on personal income tax of trust in government and legal enforcement. However, no significant relationship found between religious variables and tax evasion in Nigeria.

Boylan and Sprinkle (2001) conducted study in which he tried to explore the behavioral of the determinants of tax evasion. He used experiment technique in order to acquire desired objectives such as to identify the factors that motivate the tax compliance and characteristics of noncompliant taxpayers.

There is a clear cut difference between tax avoidance and tax evasion. One is legally accepted and the other is an offence (Skanda and Kumarasingam, 2002 as cited by James and Nobes, 2008). Tax avoidance is the legal utilization of the tax regime to one's own advantage, to reduce the amount of tax that is payable by means that are within the law. By contrast, tax evasion is the general term for efforts not to pay taxes by illegal means (Sharma and Dang 2011 as cited by Mohammed and Mohammed, 2012). It is also perceived that both tax avoidance and tax evasion are linked with shadow economy and Schneider and Enste (2000) as cited by Faseun (2001) reported that shadow economy is that economy in which people do not show their real income and taxable income that they have earned through legal activities including batter and monitory activities in order to avoid paying tax.

\section{METHODOLOGY}

\section{Research Design}

Survey research design was adopted for this study. The reason for this is that it involves investigation of opinion of large number of people and it involves inferences drawn from investigation.
The population of the study made up of Small Enterprises in Anambra State. The population being infinite, the researcher used Cochran's equation of infinite population to determine the population for the study. The sample size was determined using Cochran's equation of infinite population developed to yield a representative sample for proportions:

Formula; $\mathrm{n}_{0}=\frac{\mathrm{z}^{2} \mathrm{pq}}{\mathrm{e}^{2}}$

Where; $\mathrm{n}$ - sample size

$\mathrm{Z}$ - Abscissa of the normal curve that cuts off an area $\alpha$ at the tail (found in statistical tables which contain area under normal curve)

$\mathrm{P}$ - Estimated proportion of an attribute present in the population

$q-1-p$

e-Desired level of precision expressed in decimal.

Using a 90\% confidence interval; $Z=1.645$

$\mathrm{e}= \pm 10 \%=0.1$

$\mathrm{p}=0.5$ (maximum variable)

$\mathrm{q}=1-0.5=0.5$.

$\mathrm{n}_{0}=\frac{(1.645)^{2}(0.5)(0.5)}{(0.10)^{2}}$

$(0.10)^{2}$

$=135.30$

The questionnaire was design in a structured form and made up of general questions of two (2) research questions to be answered hypothetically and was restricted with the responses made of strongly agree (SA) agree (A) undecided (U strongly disagree (SD) and disagreed (D).

\section{Method of Data Analysis Technique}

The following statistical techniques were used in the analysis of data obtained from the study: The options to the questionnaire were arranged in a likert scale continuum of 1 to 5 with the following options: Strongly Agree (SA), Agree (A), Undecided (U), Disagree (D), and Strongly Disagree (SD). The questionnaires were analyzed five point likert's scale and hypotheses formulated for the study were tested with the t-test statistical tool with aid of Statistical Package for Social Sciences (SPSS) version 20.0 software package. 


\section{Decision rule:}

Using SPSS 5\% level of significance, if the estimated $\mathrm{t}$-value is equal or greater $\geq$ than table (critical) $\mathrm{t}$ value, we reject Null and accept alternate hypothesis.

\section{DATA \\ PRESENTATION \\ INTERPRETATION}

From table I above, out of 135 copies of questionnaires was distributed, and 98 were returned, this represent $73 \%$.

\section{Test of Hypotheses}

\section{Hypothesis One}

Ho: Personal income tax avoidance has no effect on the growth of small firms in Nigeria.

This hypothesis is tested with the responses from questions to

\begin{tabular}{|l|l|l|l|l|}
\hline One-Sample Statistics & Mean & Std. Deviation & Std. Error Mean \\
\hline Questions & N & 19.60 & 21.420 & 9.579 \\
\hline 1 & 5 & 19.60 & 19.807 & 8.858 \\
\hline 2 & 5 & 19.60 & 22.345 & 9.993 \\
\hline 3 & 5 & 19.60 & 18.649 & 8.340 \\
\hline 4 & 5 & 19.60 & 23.944 & 10.708 \\
\hline 5 & 5 & Interional & (numal & \\
\hline
\end{tabular}

\begin{tabular}{|c|c|c|c|c|c|c|}
\hline \multicolumn{7}{|c|}{ One-Sample T } \\
\hline & \multicolumn{6}{|c|}{ Test Value $=\mathbf{0}$} \\
\hline & \multirow[t]{2}{*}{$\mathbf{T}$} & \multirow[t]{2}{*}{ df } & \multirow{2}{*}{$\begin{array}{l}\text { Sig. } \\
\text { (2-tailed) }\end{array}$} & \multirow[t]{2}{*}{$\begin{array}{l}\text { Mean } \\
\text { Difference } 6470\end{array}$} & \multicolumn{2}{|c|}{$\begin{array}{l}\text { 95\% Confidence Interval of the } \\
\text { Difference }\end{array}$} \\
\hline & & & & & Lower & Upper \\
\hline 1 & 2.046 & 4 & .110 & 19.600 & -7.00 & 46.20 \\
\hline 2 & 2.213 & 4 & .091 & 19.600 & -4.99 & 44.19 \\
\hline 3 & 1.961 & 4 & .121 & 19.600 & -8.15 & 47.35 \\
\hline 4 & 2.350 & 4 & .079 & 19.600 & -3.56 & 42.76 \\
\hline 5 & 1.830 & 4 & .141 & 19.600 & -10.13 & 49.33 \\
\hline
\end{tabular}

\section{Decision:}

From the above one sample t-test table, the five questions give a positive result. The calculated t-value is 10.400 while the table $\mathrm{t}$-value is 1.812 . This means that calculated $\mathrm{t}$-value if greater than the table $\mathrm{t}$-value $(10.400>1.812)$. We therefore reject null hypothesis and uphold alternative hypothesis which states that personal income tax avoidance has effect on the growth of small firms in Nigeria. 


\section{Hypothesis Two}

Ho: Personal income tax rates and tax evasion has no effect on the growth of small firms in Nigeria.

This hypothesis is tested with the responses from questions 6 to 10 .

\begin{tabular}{|l|l|l|l|l|}
\hline One-Sample Statistics & N & Mean & $\begin{array}{l}\text { Std. } \\
\text { Deviation }\end{array}$ & Std. Error Mean \\
\hline Questions & 5 & 19.40 & 16.227 & 7.257 \\
\hline 1 & 5 & 19.60 & 16.682 & 7.461 \\
\hline 2 & 5 & 19.60 & 22.233 & 9.943 \\
\hline 4 & 5 & 19.60 & 22.300 & 9.973 \\
\hline 5 & 5 & 19.60 & 22.733 & 10.167 \\
\hline
\end{tabular}

\begin{tabular}{|c|c|c|c|c|c|c|}
\hline \multicolumn{7}{|c|}{ One-Sample Test } \\
\hline & \multicolumn{6}{|c|}{ Test Value $=0$} \\
\hline & \multirow[t]{2}{*}{$\mathbf{t}$} & \multirow{2}{*}{ df } & \multirow{2}{*}{$\begin{array}{l}\text { Sig. } \\
\text { (2-tailed) } \\
\text { Rese }\end{array}$} & \multirow{2}{*}{$\begin{array}{l}\text { Mean Difference } \\
\text { in Scientific } \\
\text { arch and }\end{array}$} & \multicolumn{2}{|c|}{$\begin{array}{l}\text { 95\% Confidence Interval of } \\
\text { the Difference }\end{array}$} \\
\hline & & & & & Lower & Upper \\
\hline 1 & 2.673 & $4 \quad 0$ & eVE & 19.400 nent & -.750 & 39.55 \\
\hline 2 & 2.627 & 40 & .058 ISSN: & $19.600=6470$ & -1.11 & 40.31 \\
\hline 3 & 1.971 & 4 & .120 & 19.600 & -8.01 & 47.21 \\
\hline 4 & 1.965 & 4 & .121 & 19.600 & -8.09 & 47.29 \\
\hline 5 & 1.928 & 4 & .126 & 19.600 & -8.63 & 47.83 \\
\hline
\end{tabular}

\section{Decision:}

From the above one sample t-test table, the five questions give a positive result. The calculated t-value is 11.164 while the table $t$-value is 1.812 . This means that calculated t-value if greater than the table t-value (11.164>1.812). We therefore reject null hypothesis and uphold alternative hypothesis which states that personal income tax rates and tax evasion has effects the growth of small firms in Nigeria.

\section{Discussion of findings}

Based on the hypotheses tested, hypothesis one stated that personal income tax avoidance has effect on the growth of small firms in Nigeria. Also hypothesis two states that personal income tax rates and tax evasion affects the growth of small firms in Nigeria.

This result is in line with Tee, Asare and Opoku (2016) findings indicate that majority of the respondents perceive the adverse impact of existing tax policies on the growth of SMEs and suggest for reforming the tax policies in the Country. Adebisi and Gbegi (2013) concluded that there is a direct and 
positive relationship between tax avoidance, tax evasion, tax rates and personal income tax administration in Nigeria.

\section{CONCLUSION AND RECOMMENDATIONS}

\section{Conclusion}

This study ascertained the effect of tax rates, evasions and avoidance of personal income taxes on the growth of small firms in Anambra State. The study indicates that there is inadequacy of personal income tax revenue to cater facilitates the growth of small firms in the state. This however, affects the growth of small firms in Nigeria. Hence personal income tax rates and tax evasion reduces the level of income that would have been injected into creating enable environment for the growth of small firms to strive off. Based on this, the study recommended as follows;

1. It is recommended that state should look inwards and develop strong strategies to enhance their personal income tax revenue.

2. The emphasis should be on enhancing direct assessment through capturing every eligible tax payer and small firms in the state, as it are only when you know the capacity of your people that you could plan successful.

\section{REFERENCES}

1. Aguolu, O (1999). Taxation and Tax Management in Nigeria, Enugu: Meridian Associates.

2. Adebisi, J. F, \& Gbegi, D.O., (2013). Effect of tax avoidance and tax evasion on personal income tax administration in Nigeria. American Journal of Humanities and Social Sciences 1(3).

3. Ariwodola, J.A. (1998). Personal income taxation in Nigeria including capital gains tax, Lagos: JAA Nigeria.

4. Ayua, LA. (1999). The Nigerian Tax Law, Ibadan: Spectrum Law Publishing.

5. Ariyo, A. (1997). Productivity of the Nigerian tax system: 1970 - 1990". african economic research consortium (AERC)', Research Paper 67, Nairobi Kenya: AERC. Available from: http://www.aercafrica.org/DOCUMENTS/RP67.P DF. Accessed 28/06/10.

6. Ali-Nayea, A., 2008. Taxation in Ghana: Princiles,practice and planning.. s.1.:Black Mask Limited.
7. Aryeetey, E., (2001). Priority Research Issues Relating to Regulation and Competition in Ghana. Manchester, University of Manchester.

8. Aryeetey, E. \& Ohene, A., (2004). Changing regulatory environment for smal-medium size enterprises and their performance in Ghana.. s.1., Working Paper, p. 300594.

9. Atawodi, O. W. \& Ojeka, S. A., (2012). Factors that affect tax compliance among small and medium enterprises (SMEs) in north central Nigeria.. International journal of business and management, 7(12).

10. Ayodele, 0. (2006). Tax policy reform in Nigeria", World Institute for Developmental Economic Research (WIDER) Research Paper, Vol. 2006/03. Finland: UNIt-WIDER. Retrieved from: http://www.wider.unu.edu/publications/ workingpapers/researchpaperg/2oo6/enGB/20oo $03 /$.

11. Allingham, M. \& Sadmo, A. (1972). Income Tax evasion: A theoretical analysis, Journal of Public Economics, 1,323-338.

12. Boylan, S. \& Sprinkle, C. (2001). Experimental evidence on the relation between tax rates and compliance': The. Effect of Earned vs. Endowed Income: Journal of the American Taxation Association, 23(1), 75-99.

13. Bank, W., (2004). Investment Climate Assessment, Improving Enterprise Performance, s.l.: World Bank.

14. Baurer, L. I., (2005). Tax Administration and Small and Medium Entreprises (SMEs) in Development Countries. s.1.:s.n.

15. Balyewu, F.A. (2000). Nigerian Taxation: A Practical Approach, Egbe Kogi: Bhoti International Publishing Ltd.

16. Collins, J. \& Hussey, R. (2003). "Business Research a practical guide for undergraduate and post graduate students", Ed. New York: Paigrave Macmillan.

17. Chipeta, C., 2002. The Second Economy and Tax Yield in Malawi.. Nairobi, s.n., p. Paper No. 113.

18. Evans, M. R (2009). Aba Women's Riot (November — December 1929)".Blackpast.org. Retrieved 
International Journal of Trend in Scientific Research and Development (IJTSRD) ISSN: 2456-6470

http://www.blaclcpast.org/?q=gab/abawomensriots.

19. Tee, E., Boadi, L. A. \& Opoku, R. .T (2016). The effect of tax payment on the performance of SMEs: The Case of Selected SMEs in Ga West Municipal Assembly. European journal of business and management www.iiste.org ISSN 2222-1905 (Paper) ISSN 2222-2839 (Online) $8(20)$.

20. Fagbemi, O. T., Uadile, O. M. \& Noah, A. O., (2010). The ethics of tax evation: perpetual evidence from Nigeria.. European Journal of Social Sciences, 17(3), pp. 360-371.

21. Farayole, 0.0. (1987). Guide to Nigerian Taxes, Lagos: All Crowns Nig. Ltd.

22. Faseun L.A. (2001). Tax Planning” Lagos Tax the Newsletter of CITN, Lagos: District Society 1(1).

23. Fisher, R., Coddeeris, J. \& Young, J. (1989). Participation in Tax Amnesties: The Individual Income Tax'": National Tax Journal, 42(2), 15 27.

24. James, S. \& Nobes, C. (2008). The Economics of Taxation', 8th ed, Birmingham. Fiscal Publications. Kiabel, D.B. and Nwokah, G N. (2009). "Boosting Revenue Generation by State Governments in Nigeria":

25. James, S. \& Nobes, C. (2009). "Economics for Taxation', 9th ed. Birmingham: Fiscal publications.

26. Kiabel, B .D. (2001). Personal income Tax ill Nigeria, Owerri: Springfield Publishers.

27. Lefebvre, M., Pestleau, P., Riedl, A. \& Villeval, M. C. (2011). Tax Evasion, Welfare Fraud, and the Broken Windows Effect: An Experiment in Belgium, France and the Netherlands. LZA Discussion Paper No. 509.

28. Laffer, A. (2009). Taxes, Depression, and Our Current Troubles', Wall Street Journal, 22" Sept. Eastern Edition. Retrieved from: http://www.proquest.com/.

29. Muhammed, M.M., Muhanimed, A. (2012). Reasons of Tax avoidance and tax evasion': Reflection from Parkistan.

30. Marti, L. O., (2010). Taxpayers' attitudes and tax compliance behaviour in Kenya.. African journal of business and management, Volume 1, pp. 112122.
31. Mnewa, R. \& Maliti, E., (2008). The role of small business in poverty alleviation: The case of Dar es Salaam,Tanzarnia.. s.1., Research Report.

32. Nassar, M.L. \& Fasina, H.T. (2005). Ipact of Personal Income Tax on Internally Generated Revenue Performance in Oyo State. International Journal of African Culture and Ideas, Vol 5, No 1, $1-10$.

33. Nigeria (2006). Tax assessment procedure. FIRS Information Circular No: 2006/04, February 2006. Retrieved from: http://www.firs.gov.ng/CMSTemplates/FIRS_S4E / download ds/Tax_Assessment_Procedure.pdd.

34. Nigeria (2009). Capital gains tax" Federal Inland Revenue Services. Retrieved from: http://www.firs.gov.ng/capital-gains-tax.aspx.

35. Nigeria (2009). Education Tax" Federal Inland Revenue Services Retrieved from: http://www.firs.gov.ng/education-tax.aspx.

36. Nigeria (2009). Information Technology Development Levy" Federal Inland Revenue Services.al Retrieved from: http :f/www.firs.gov.ng/information-technologydevelopmeht-levy.aspx.

37. Nigeria (2009). Petroleum Profits Tax Act (PPTA) Federal Inland Revenue Services. Retrieved from: http://www.firs.gov.nglpetroleum-profits-tax.aspx.

38. Nigeria (2009). Stamp Duties, Federal Inland Revenue Services. Retrieved from: http://www.firs.gov.ng/stamp-duties.aspx.

39. Oludele, A. A. \& Emilie, C. K., (2012). Regulation, Awareness, Compliance and SME Performance in Cameroon's Manufacturing and Retail Sectors.. International Journal of Social Economics, 39(12).

40. Pope, J. \& Abdul-Jabbar, H., (2008). Tax compliance costs of small and medium enterprises in Malasia: Policy Implications. Malasia: s.n.

41. Steenekamp, T. (2012). The progressivity of personal income tax in South Africa since 1994 and directions for tax reform. . Southern African Business Review, Volume 16 Number 12012.

42. UNIDO, (2009). Tanzarnia small and medium scale enterprises policy proposal, Tanzarnia: s.n.

43. William G. G \& Andrew A. S. (2014). Effects of Income Tax Changes on Economic Growth. American Economic Review , 91 (3): 574-95 